\title{
IMPLEMENTASI STRATEGI PENERAPAN KARTU \\ TANDA PENDUDUK ELEKTRONIK (e-KTP) \\ DI KABUPATEN MAMASA
}

(Studi Kasus UPT. Kependudukan dan Pencatatan Sipil Kecamatan

Sumarorong)

\author{
Barnesi Datumongan 1 \\ ${ }^{1}$ Prodi Ilmu Pemerintahan, Fakultas Ilmu Sosial dan Ilmu Pemerintahan \\ Universitas Al Asyariah Mandar \\ Email: ahmadisra9751@gmail.com \\ Martinus Sudi² \\ ${ }^{1}$ Prodi Ilmu Pemerintahan, Fakultas Ilmu Sosial dan Ilmu Pemerintahan \\ Universitas Al Asyariah Mandar \\ Email: martinsudi@gmail.com
}

\section{ABSTRACT}

This study aims to determine the implementation of the strategy for implementing Electronic Identity Cards (e-KTP) in Mamasa Regency and the efforts made in implementing Electronic Identity Cards (e-KTP) in Mamasa Regency. This research used qualitative methods and the type of data collection used document review, interviews and observation. The results of the study show that the standard procedures for implementing Electronic KTP 2011 are through strategic programs in the form of organizational structures on behalf of regency and sub-district working groups, socialization, program implementers (HR), provision of facilities and infrastructure and population mobilization. Of these activities $44.30 \%$ have been realized with various obstacles, including slow distribution of equipment from the center and only one functioning, damaged equipment, and inaccessibility of some residents due to delays in mobile registration which are expected to be an alternative.

\section{ABSTRAK}

Penelitian ini bertujuan untuk mengetahui implementasi strategi implementasi Kartu Tanda Penduduk Elektronik (e-KTP) di Kabupaten Mamasa dan upaya yang dilakukan dalam implementasi Kartu Tanda Penduduk Elektronik (e-KTP) di Kabupaten Mamasa. Penelitian ini menggunakan metode kualitatif dan jenis pengumpulan datanya menggunakan telaah dokumen, wawancara dan observasi. Hasil penelitian menunjukkan bahwa prosedur standar pelaksanaan KTP Elektronik 2011 melalui program-program strategis berupa struktur organisasi atas nama kelompok kerja kabupaten dan kecamatan, sosialisasi, pelaksana program (SDM), penyediaan sarana dan prasarana dan mobilisasi penduduk. Dari kegiatan tersebut 
$44,30 \%$ telah terealisasi dengan berbagai kendala, antara lain lambatnya distribusi peralatan dari pusat dan hanya satu yang berfungsi, peralatan rusak, serta tidak dapat diaksesnya sebagian warga akibat keterlambatan registrasi keliling yang diharapkan dapat menjadi alternatif.

Kata Kunci: Implementasi, e-KTP, strategi.

\section{PENDAHULUAN}

Salah satu tugas pemerintah adalah memberikan pelayanan yang baik kepada masyarakat sebagaimana diatur dalam Undang-Undang Nomor 25 Tahun 2009 tentang Pelayanan Publik. Salah satu upaya yang dapat dilakukan sehubungan dengan hal tersebut yaitu mengoptimalkan penggunaan Teknologi Informasi dan Komunikasi.

Kemajuan teknologi informasi memberikan manfaat yang sebesarbesarnya untuk kemaslahatan masyarakat. Tentunya dalam dunia yang sudah mengglobal ini, kemajuan teknologi diperlukan dan dimanfaatkan dalam segala bidang. Salah satu bidang yang terkena sentuhan teknologi informasi adalah pelayanan pemerintah kepada publik.

Pelayanan merupakan tugas utama yang hakiki dari sosok aparatur,sebagai abdi negara dan abdi masyarakat. Tugas ini telah jelas digariskandalam pembukaan Undang-UndangDasar 1945 pada alinea keempat, yang meliputi 4 (empat)aspek pelayanan pokok aparatur terhadap masyarakat, yaitu melindungisegenap bangsa Indonesia dan seluruh tumpah darah Indonesia, memajukankesejahteraan umum, mencerdaskan kehidupan bangsa dan melaksanakanketertiban dunia yang berdasarkan kemerdekaan, perdamaian abadi dankeadilan sosial.Selain itu, diperjelas lagi dalam Keputusan MenteriPendayagunaan Aparatur Negara Nomor 63 tahun 2003 yang menguraikanpedoman umum penyelenggaraan pelayanan publik.

Pelayanan publik yang berkualitas atau yang biasa disebut denganpelayanan prima merupakan pelayanan terbaik yang memenuhi standarkualitas pelayanan. Standar Pelayanan adalah tolok ukur yang dipergunakansebagai pedoman penyelenggaraan pelayanan dan acuan penilaian kualitaspelayanan sebagai kewajiban dan janji penyelenggara pelayanan kepadamasyarakat dalam rangka pelayanan yang berkualitas, cepat, mudah,terjangkau, dan terukur. Menurut Peraturan Menteri PendayagunaanAparatur Negara Dan Reformasi Birokrasi Republik Indonesia Nomor 15Tahun 2014 tentang Komponen Standar Pelayanan, disebutkan bahwa komponen standar pelayanan yang terkait dengan prosespenyampaian pelayanan meliputi persyaratan, prosedur, jangka waktupelayanan, biaya/tarif, produk pelayanan, dan penanganan pengaduan. Jika suatu Instansi pemerintah 
dan lembaga lainnya mampu menerapkan standarkualitas tersebut maka sudah dapat dikatakan bahwa Instansi pemerintahdan lembaga tersebut telah memberikan kualitas pelayanan yang baik.

Pelayanan publik merupakan segala kegiatan dalam rangkapemenuhan kebutuhan dasar sesuai dengan hak-hak dasar setiap warganegara atau penduduk atas suatu barang, jasa dan pelayanan administrasiyang disediakan oleh penyelenggara pelayanan yang terkait dengankepentingan publik.

Pada dasarnya sistem administrasi kependudukan merupakan sub sistem darisistem administrasi negara, yang mempunyai peranan penting dalam pemerintahandan pembangunan penyelenggaraan administrasi kependudukan. Hak asasi setiaporang di bidang pelayanan administrasi kependudukan, peningkatan kesadaranpenduduk dan kewajibannya untuk berperan serta dalam pelaksanaan administrasikependudukan, pemenuhan data statistik kependudukan dan statistik peristiwakependudukan, dukungan terhadap perencanaan pembangunan sistem administrasikependudukan guna meningkatkan pemberian pelayanan publik tanpa diskriminasi(Mulyo, 2013: 32). Sejalan dengan arah penyelenggaraan administrasi kependudukan,maka pendaftaran penduduk dan pencatatan sipil sebagai sub-sub sistem pilar dariadministrasi kependudukan perlu ditata dengan sebaik-baiknya agar dapat memberikan manfaat dalam perbaikan pemerintahan dan pembangunan.

Kemajuan teknologi yang sangat cepat mengharuskan instansi mengikutiperkembangan teknologi. Perkembangan Teknologi Informasi yang kian pesatmenimbulkan suatu revolusi baru berupa peralihan sistem kerja yang konvensional keera digital. Perubahan ini juga telah merubah cara pandang setiap orang dalammelakukan berbagai kegiatan yang salah satunya adalah pada kegiatan instansi pemerintah.

Untuk itu, suatu instansi pemerintah membutuhkan suatu sistem informasi yang mendukung kebutuhan instansi pemerintah dalam menciptakan efisiensi dan efektifitas kerjamaupun dalam meningkatkan pelayanan kepada masyarakat (Mulyo, 2013: 33). Salah satu pelayanan terhadap masyarakat adalah pengelolaan pendaftaranpenduduk yang merupakan tanggung jawab pemerintah kota/kabupaten, dimanadalam pelaksanaannya diawali dari desa/kelurahan selaku ujung tombak pendaftaranpenduduk, hingga setiap warga terdaftar secara administrasi sebagai warga negaraIndonesia dan sesuai dengan Undang-Undang Nomor 23 Tahun 2006 tentangAdministrasi Kependudukan. Dalam pelayanan tersebut perlu dilakukan dengan benardan cepat agar penduduk sebagai pelanggan merasa mendapat pelayanan yangmemuaskan.

Sebagai salah satu langkah untuk membantu berbagai pekerjaan mengenaipendaftaran kependudukan yang sesuai dengan berbagai standar yang 
diperlukan,maka pemerintah mulai membuat sebuah kebijakan dengan mengadakan programyang dahulu dikenal dengan Sistem Informasi Manajemen Kependudukan(SIMDUK) yang dibuat sekitar tahun 1996. SIMDUK adalah sebuah kebijakan yangditerapkan di daerah kabupaten/kota, dan ditujukan untuk menangani statuskependudukan dengan segala perubahannya. SIMDUK itu sendiri merupakan suatuaplikasi untuk mengelola data kependudukan daerah yang meliputi Kartu Keluarga(KK), Kartu Tanda Penduduk (KTP), Akte Kelahiran, Sensus Penduduk, danDemografi Penduduk. Aplikasinya dapat digunakan untuk mengelola datakependudukan pada kecamatan atau kelurahan yang lokasinya terpisah, akan tetapi karena didasarkan pada basis internet maka dapat dikumpulkan di satu titik yaituInternet Data Center(PT. Telematika, 2016).

Namun pada pelaksanaannya di lapangan, ternyata didapati berbagaikelemahan SIMDUK sebagai sebuah sistem untuk mengelola data kependudukan.Dimana masih banyak terdapat pemalsuan identitas karena disebabkan kurangdetailnya data-data mengenai penduduk. Seperti yang terdapat di Kabupa tenMamasa, dimana ditemukan adanya beberapa identitas ganda (nama dan alamat sama) dengan nomor identitas yangberbeda, demikian pula halnya di daerah-daerah lainnya. Berdasarkan berbagai evaluasi terhadapkebijakan SIMDUK ini, pemerintah merasa perlu menggantinya dengan sebuahkebijakan yang baru. Kebijakan baru itu tentunya juga lebih menjawab segalakebutuhan yang diperlukan untuk melengkapi data kependudukan. Untuk membantuberbagai pekerjaan mengenai pendaftaran kependudukan yang sesuai denganberbagai standar yang diperlukan, maka pemerintah merumuskan sebuah kebijakanbaru. Salah satunya adalah dengan mengeluarkan Inpres Nomor 3 Tahun 2003tentang Elektronik Government (CV.Artha Mitra Pratama, 2015).

Salah satu pendorong penerapan e-Government adalah untuk meningkatkanefisiensi, efektifitas, transparansi dan akuntabilitas dalam penyelenggaraanpemerintahan. Dalam penyusunan rencana strategis pengembangan e-Government,pemerintah memiliki peranan sebagai pemberi kebijakan tentang strategi pengembangan e-Government, dalam hal ini Inpres tersebut memberikan arahanpenyusunan tentang rencana strategis eGovernment kepada seluruh instansi pemerintahan sesuai dengan konteks masing-masing dari lingkungan instansitersebut.

Menurut Inpres Nomor 3 Tahun 2003 tentang Kebijakan dan Strategi Nasional Pengembangan e-Governmet, dikatakan bahwa pengembangan eGovernment merupakan upaya untuk mengembangkan penyelenggaraan kepemerintahan yang berbasis (menggunakan) elektronik dalam rangka meningkatkan kualitas layanan publik secara efektif dan efisien. Melalui pengembangan e-government dilakukan penataan sistem manajemen dan 
proses kerjadi lingkungan pemerintah dengan mengoptimasikan pemanfaatan teknologi informasi.

Pemanfaatan teknologi informasi tersebut mencakup 2 (dua) aktivitas yang berkaitan, yaitu:

1. Pengolahan data, pengelolaan informasi, sistem manajemen dan proses kerjasecara elektronis.

2. Pemanfaatan kemajuan teknologi informasi agar pelayanan publik dapatdiakses secara mudah dan murah oleh masyarakat.

Banyaknya data yang dikelola dan perlunya penyampaian informasi yangcepat dalam kegiatan pelayanan administrasi kependudukan menjadikan teknologiinformasi sebagai media yang dianggap mampu dan handal untuk membantu dalampengelolaan data dan penyajian informasi yang cepat, mudah dan akurat. Kemudiansebuah penerapan teknologi hendaknya memenuhi prinsip-prinsip tepat guna (appropriate) mendukung sistem pelayanan administrasi kependudukan, bertahanrelatif lama (long life) tidak mudah rusak(face out), efisien (tidak over investment atau under investment), aman (secure), mudah dioperasionalkan (user friendly), dan murahpemeliharaannya, serta dapat diakses di seluruh wilayah tanah air dengan supportyang selalu tersedia dan relatif cepat. Dalam mendukung pelayanan administrasi kependudukan, penerapan teknologi sangat penting untuk menjawab keamanan(security) dan kecepatan dalam proses perekaman, pengiriman/ komunikasi data, penyimpanan serta pendayagunaan data individu penduduk (PT.Unisystem Utama,2015).

Penerapan teknologi informasi dalam e-Government ini diantaranya adalahpenggunaan Sistem Informasi Administrasi Kependudukan (SIAK). SistemInformasi Kependudukan adalah salah satu jenis perangkat lunak yang dapatdigunakan untuk membantu proses pengelolaan data dan pencatatan biodata pendudukpada salah satu instansi pemerintah yang bergerak dalam bidang pelayananadministrasi kependudukan. SIAK merupakan suatu sistem informasi berbasis webyang disusun berdasarkan prosedur-prosedur dan memakai standarisasi khusus yangbertujuan menata sistem administrasi dibidang kependudukan sehingga tercapai tertibadministrasi dan juga membantu bagi petugas dijajaran pemerintah daerah khususnyaDinas Kependudukan dan Catatan Sipil didalam menyelenggarakan layanan kependudukan. SIAK bisa menjadi solusi dari masalah kependudukan yang ada.

Dengan adanya pengelolaan data secara online maka kelemahankelemahanpengolahan data secara konvensional dapat ditekan. SIAK sendiri memberikanbanyak manfaat antara lain, hasil perhitungan dan pengelolaan 
data statistik tersebutdapat digunakan sebagai bahan perumusan dan penyempurnaan kebijakan, strategi dan program bagipenyelenggaraan dan pelaksanaan pembangunan di bidang kualitas,kuantitas, dan mobilitas penduduk, serta kepentingan pembangunan lainnya (Agung, 2015).

Disamping itu SIAK dirancang, dibangun dan dikembangkan sesuai denganprinsip-prinsip di atas untuk mampu menyelenggarakan penerbitan NIK Nasionalsebagai nomor identitas tunggal (unique) yang ditampilkan pada setiap dokumenkependudukan, dan sebagai kunci akses untuk verifikasi data diri maupun identifikasijati diri seseorang yang sangat berguna di dalam mewujudkan efisiensi dan efektifitaspelayanan publik. Sejalan dengan itu, aspek material untuk penerbitan dokumenkependudukan, misalnya penerbitan KTP juga harus terjamin kualitas keamanannyadalam mendukung nilai serta keaslian dokumen, yaitu dengan menerapkan securityfeature teknologi yang tepat guna. Issue keamanan (security) dalam hal ini bermaknaganda, yaitu bagi penduduk/pemegang dokumen dapat memberikan rasa aman,nyaman, kepastian hukum (perlindungan dan pengakuan negara/pemerintah) atasdatainformasi status kependudukan atau peristiwa vital yang tertera dalam dokumen.

Sedangkan bagi pemerintah, dokumen kependudukan yang terjamin keasliannya danvalid data informasi di dalamnya dapat berfungsi mengendalikan penduduk untukkepentingan nasional, serta bagi penyelenggara pelayanan publik dapat membantumendukung terwujudnya pelayanan yang efisien dan efektif (PT.Unisystem Utama,2015).

Hal-hal seperti tersebut di atas telah diintegrasikan dalam bentuk kartu tandapenduduk elektronik (e-KTP) sebagai salah satu strategi yang diharapkan mampumenjadi pilar elektronik Government dalam memberikan peningkatan pembangunandan perencanaan pembangunan dimasa yang akan datang. Satu perubahan besar yangdimunculkan melalui e-KTP atau KTP Elektronik adalah dokumen kependudukanyang memuat sistem keamanan/pengendalian baik dari sisi administrasi ataupunteknologi informasi dengan berbasis pada database kependudukan nasional.Penduduk hanya diperbolehkan memiliki satu KTP yang tercantum Nomor IndukKependudukan (NIK) yang merupakan identitas tunggal setiap penduduk dan berlakuseumur hidup. NIK yang ada di e-KTP nantinya akan dijadikan dasar dalampenerbitan Paspor, Surat Izin Mengemudi (SIM), Nomor Pokok Wajib Pajak(NPWP), Polis Asuransi, Sertifikat atas Hak Tanah dan penerbitan dokumen identitaslainnya (Pasal 13 Undang-Undang Nomor 23 Tahun 2006 tentang Administrasi Kependudukan).

KTP Elektronik ini, pada dasarnya akan diberlakukan secaranasional di seluruh Indonesia, namun pemerintah pusat memberlakukanpenerapannya secara bertahap, yaitu di Tahun 2011 diterapkan di 197 kabupaten/kota,dan 
ditahun 2012 berada di 300 kabupaten/kota. Khusus untuk Sulawesi Barat,dari 6 Kabupaten pada Tahun 2013 menerapkan e-KTP dantermasuk diantaranya Kabupaten Mamasa.

Sejak penetapan tersebut, banyak hal menarik yang terjadi dalam penerapan e-KTP ini di Kabupaten Mamasa, diantaranya adalah terungkap saat adanya hearingantara pemerintah Kabupaten Mamasa dengan DPRD bahwa ketersediaan listrik di Dinas Kependudukan Dan Pencatatan Sipil Kabupaten Mamasa tidak terjamin,sehingga mengganggu proses penerapan program pusat tersebut.

Dalam pelaksanaan bimbingan teknis mengenai materi umum dan tata carapenerbitan e-KTP mulai dari perekaman data seperti perekaman sidik jari,tandatangan dan iris mata, yang digelar diKantor Bupati Mamasa padatanggal 2 Agustus 2013, dan dihadiri sekitar 40 orang dari staf Kecamatan dan DinasKependudukan dan Catatan Sipil Kabupaten Mamasa yang seyogyanya pelatihan tersebutditunjang perangkat/alat, namun pertemuan itu hanya materi yang sifatnyapenyampaian dan penggambaran spesifikasi, sehingga tidak maksimal.

Disamping itu, menurut Sekretaris Camat Kecamatan Sumarorong bahwa kendala yang saat ini kecamatan hadapi adalah alat yangdidistribusikan oleh pemerintah pusat baru satu yang berfungsi, sehingga jumlahmasyarakat yang dimobilisasi ketempat pelayanan masih kurang, dan kendala lainnyakarena cuaca di Kecamatan Sumarorong dan Kecamatan lainnya di Kabupaten Mamasa yang sangat mengganggu signal,sehingga antrian yang mestinya dapat diselesaikan 30 KK perharinya sangat kurang daritarget tersebut.Bahkan dibeberapa Kecamatan telah diberlakukan pelayanan seminggu penuh,namun diperkirakan pencapaian target $100 \%$ untuk akhir Desember 2017 masihterkendala.

Sangat disadari bahwa penerapan KTP Elektronik sesungguhnya akanmengalami banyak kendala, disamping karena merupakan inovasi baru dan sifatnyatop down, sehingga strategi yang telah ditetapkan oleh pusat melalui KementrianDalam Negeri tentu tidak serta merta dapat diimplementasikan dengan cepat, tepat dan berhasil $100 \%$ oleh setiap daerah. Dinamika organisasi dan kondisi geografissetiap Kabupaten/Kota sangat mempengaruhi efektifitas dan efiensi penyelenggaraanpenerapan KTP Elektronik ini.

\section{METODE PENELITIAN}

Metode penelitian adalah ilmu tentang proses dan aturan penelitian termasuk didalamnya asumsi, nilai dan standar yang dipakai dalam proses 
penelitian secara teknik yang dipakai dalam mengumpulkan dan menganalisa data (Ali, 2009:15).

Berdasarkan fokus masalah yang telah dirumuskan dan tujuan penelitian yang telah dipaparkan sebelumnya, maka penelitian ini diarahkan untuk mengungkapkan secara mendalam bagaimana implementasi strategi penerapan e-KTP di Kabupaten Mamasa, oleh karena itu metode atau pendekatan yang digunakan dalam penelitian ini adalah pendekatan kualitatif yangakan mengungkap implementasi strategi melalui dari program, anggaran dan prosedur dalam penerapan e-KTP di Kabupaten Mamasa untuk mencapai efektifitas.

\section{HASIL PENELITIAN}

\section{Implementasi Strategi Penerapan e-KTP di Kabupaten Mamasa}

\section{Implementasi Strategi Dari Segi "Program"}

Dalam melaksanakan program penerapan KTP elektronik, Dinas Kependudukan dan Catatan Sipil Kabupaten Mamasa membuat persiapanpersiapan diantaranya adalah :

a. Pembentukan Struktur Organisasi dalam bentuk Kelompok Kerja

Kelompok Kerja pelaksana penerapan e-KTP secara teknis telah diberikan petunjuknya oleh Kementerian Dalam Negeri Republik Indonesia Cq Direktorat Jenderal Kependudukan dan Pencatatan Sipil, dimana pokja tersebut terbagi atas Pokja Kabupaten dan Pokja Kecamatan. Merujuk pada petunjuk tersebut, Dinas Kependudukan Dan Pencatatan Sipil Kabupaten Mamasa kemudian membuat Surat Keputusan Bupati dengan Nomor 1076 Tahun 2011 tentang Pembentukan Kelompok Kerja (Pokja) Pelaksana Penerapan Kartu Tanda Penduduk Elektronik Tingkat Kabupaten dan Tingkat Kecamatan Tahun 2011 dengan susunan sebagai berikut: adalah :

Adapun tugas pokja penerapan KTP Elektronik tingkat Kabupaten

1) Melakukan sosialisasi penerapan KTP Elektronik kepada instansi pemerintah dan non pemerintah ditingkat Kabupaten dan pokja Kecamatan, tokoh masyarakat, tokoh agama, masyarakat umum dan penduduk.

2) Melakukan pengawasan dan supervise pelaksanaan pelayanan KTP Elektronik ditempat-tempat pelayanan.

3) Membantu memilah hasil cetakan (print out) surat panggilan wajib KTP per Desa/Kelurahan dan mengirimkan ke Kecamatan. 
4) Membuat dan menyampaikan laporan pelaksanaan penerapan KTP Elektronik secara massal Kabupaten kepada Gubernur melalui Bupati, tembusannya disampaikan kepada Menteri Dalam Negeri.

Kelompok kerja berlaku sejak 09 September 2011, hal ini lambat dibuat karena keterlambatan pemerintah pusat mendistribusikan petunjuk teknisnya, yang mana semula dijadwalkan Agustus 2011 sehingga pelaksanaannya di bulan berikutnya (Kabid Pendataan Dan Informasi Penduduk Kabupaten Mamasa).

b. Sosialisasi

Sasaran sosialisasi penerapan KTP elektronik adalah instansi terkait dan penduduk, dalam hal ini dimulai dari Ketua RT, Ketua RW, Kelurahan dan Kecamatan untuk menyampaikan kepada masyarakat dan memberikan pengertian bahwa mulai tahun 2011 akan diterbitkan KTP Elektronik yang dilengkapi dengan chip sebagai penyimpan biodata, pas photo, tanda tangan serta sidik jari telunjuk tangan kanan dan kiri penduduk, sehingga tidak boleh diwakilkan.

Dalam pensosialisasian KTP Elektronik, dikoordinir melalui Kepala UPT Pencatatan Sipil Dan Pelayanan Kependudukan Kabupaten Mamasa. Menurut Bapak Kepala unit pelaksana teknis Pencatatan Sipil Dan Pelayanan Kependudukan bahwa:

"Sosialisasi penerapan e-KTP dalam bentuk tatap muka yaitu dimulai dari sosialisasi Kabupaten sampai ke tiap Kecamatan diseluruh Kabupaten Mamasa, dengan mengundang tokoh agama, tokoh masyarakat, berbagai organisasi aktif didaerah, lembaga sosial dan penduduk lainnya untuk datang ditempat yang telah disediakan kemudian menjelaskan adanya program penerapan KTP Elektronik di Kabupaten Mamasa. Sehingga sosialisasi ini berlangsung di sepuluh tempat, satu kali di Kabupaten dan Sembilan Kecamatan." (Wawancara, 08 Maret 2019)

Dari data tersebut, peneliti mengasumsikan bahwa Dinas Kependudukan dan Pencatatan Sipil telah berupaya memaksimalkan pensosialisasian KTP Elektronik secara menyeluruh di Kabupaten Mamasa karena sosialisasi ini dilaksanakan di semua Kecamatan tanpa terkecuali. Ini berarti Unit pelaksana Tekhnis di Setiap Kecamatan sejak awal adanya program ini telah siap dengan segala persiapan baik dari segi bahan sosialisasi maupun dari segi sumber daya manusia dan materi lainnya.

Disamping sosialisasi secara tatap muka, dari pantauan peneliti dan hasil wawancara dengan Kasi Pendaftaran Penduduk Kabupaten Mamasa dikatakan bahwa: 
"Sosialisasi penerapan e-KTP disebarkan pula melalui berbagai media diantaranya, media elektronik, media Cetak melalui "Radar Sulbar, Baliho diberbagai tempat strategis, Leaflet serta Stiker yang ditempelkan diberbagai tempat. Hal ini dilakukan dalam rangka memaksimalkan penerapan KTP Elektronik sebagai kebijakan kependudukan, agar masyarakat ikut andil dan antusias dan paham serta mau untuk mendatangi tempat pelayanan e-KTP karena melihat langsung ajakan tersebut dan tidak hanya mendengar dari mulut kemulut" (Wawancara, 08 Maret 2019).

c. Pembentukan Pelaksana Program (Sumber Daya Manusia)

Pelaksana program dalam hal ini sumber daya manusia yang akan menjalankan penerapan e-KTP tidak kalah pentingnya dalam pelaksanaan ini, karena sukses tidaknya program tersebut tentu karena kiprah dan kesiapan serta pengetahuan yang dimiliki oleh penyelenggara itu sendiri. Dalam hal ini sebagaimana petunjuk teknis yang diterbitkan oleh Kementerian Dalam Negeri bahwa petugas pelayanan penerapan e-KTP adalah operator, petugas pendukung dan supervisor teknis yang mana pengangkatannya ditetapkan dengan Keputusan Bupati Kabupaten Mamasa.

Sebagaimana yang peneliti jelaskan sebelumnya, bahwa dalam rangka efisiensi dan efektifitas UPT Kamatan dalam menerbitkan Surat Keputusan Bupati, merangkum secara global tanpa mengurangi tujuan yang diinginkan, sehingga operator, petugas pendukung dan supervisor teknis telah berada dalam satu kesatuan sebagai anggota pokja.

Adapun tugas dan fungsi masing-masing petugas tersebut adalah:

1) Operator

Jumlah operator yang ditugaskan disetiap tempat pelayanan KTP Elektronik 3 orang untuk mengoperasikan dua set perangkat KTP elektronik. Kualifikasi operator adalah Pegawai Negeri Sipil, bisa mengoperasikan komputer dan telah mengikuti bimbingan teknis operator penerapan KTP elektronik. Operator mempunyai tugas:

a) Melakukan verifikasi biodata penduduk yang terdapat dalam data base kependudukan ditempat pelayanan

b) Melakukan perekaman pas photo, tanda tangan, sidik jari dan iris mata

c) Memastikan keberhasilan perekaman sidik jari penduduk dengan melakukan verifikasi sidik jari. Verifikasi sidik jari dilakukan dengan cara mengulang kembali perekaman sidik jari telunjuk kanan dan kiri yang akan disimpan dalam chip.

d) Meminta penduduk melakukan pengesahan hasil verifikasi data, perekaman pas photo, tanda tangan, sidik jari dan iris dengan cara 
membubuhkan tanda tangan secara elektronik pada perekam tanda tangan yang disediakan sebagai bukti persetujuan terhadap kebenaran data penduduk yang bersangkutan

e) Melakukan penyimpanan hasil perekaman pas photo, tanda tangan, sidik jari, dan iris serta dokumen pengesahan secara elektronik yang telah dilakukan sebagaimana pada angka 2 dan 4 ke dalam database pelayanan

f) Bertanggungjawab terhadap beroperasinya perangkat KTP Elektronik dan perangkat jaringan komunikasi data di tempat pelayanan KTP Elektronik

g) Bertanggungjawab terhadap back up data dan pengamanan database kependudukan.

2) Tenaga Pendukung Pelayanan

Tenaga pendukung pelayanan KTP Elektronik di tempat Unit pelaksana tekhnis di tiap Kecamatan di Kabupaten Mamasa, ditempatkan 1 orang mengingat volume pekerjaan dan jumlah penduduk belum signifikan. Adapun tugas tenaga pendukung pelayanan adalah:

a) Menerima surat panggilan dan KTP lama dari penduduk dan mencocokkan dengan daftar penduduk wajib KTP serta memberikan nomor panggilan.

b) Menyerahkan surat panggilan dan KTP lama kepada petugas operator

c) Mengumumkan dan memberitahukan kepada penduduk wajib KTP untuk membersihkan dan mengeringkan jari tangan dan tidak memakai kacamata atau lensa kontak mata sebelum masuk ruangan pelayanan guna mempermudah perekam sidik jari tangan dan iris.

d) Menerima kembali surat panggilan dan KTP lama serta nomor antrian dari petugas operator dan membubuhkan tanda tangan dan stempel tempat pelayanan KTP Elektronik sabagai bukti telah selesai proses pelayanan perekaman pada surat panggilan penduduk.

e) Menyerahkan kembali KTP lama dan surat panggilan yang telah ditandatangani dan distempel kepada penduduk yang bersangkutan serta menyimpan nomor antrian.

3) Petugas Supervisi Teknis

Petugas supervise teknis diutamakan Pegawai Negeri Sipil dan pejabat eselon IV dan bisa mengoperasikan komputer serta telah mendapat bimbingan teknis penerapan KTP Elektronik. Petugas supervise teknis mempunyai tugas :

a) Melakukan koordinasi dengan pokja ditempat pelayanan dan instansi teknis untuk kelancaran pelaksanaan pelaayanan KTP Elektronik 
b) Membuat rencana dan jadwal pelaksanaan pelayanan menggunakan perangkat e-KTP bergerak (mobile enrollment)

c) Melakukan pengecekan ketersediaan catu daya listrik, kesiapan perangkat, kesiapan tempat dan sarana pelayanan, kesiapan tenaga pendukung dan operator.

d) Mengawasi dan mengatur pelaksanaan verifikasi biodata penduduk dan perekaman pas photo, tanda tangan, sidik jari dan iris penduduk.

e) Mengawasi dan mengatur pelaksanaan pelayanan pengambilan KTP Elektronik.

f)"Melakukan pengiriman hasil verifikasi data penduduk dan hasil perekam pas photo, tanda tangan, sidik jari dan iris penduduk dari tempat pelayanan ke pusat Data Kependudukan Direktorat Jenderal Kependudukan dan Pencatatan Sipil Kementerian Dalam Negeri secara khusus, apabila jaringan komunikasi data tidak berfungsi.

g) Mengontrol dan mengecek back up data dan pengadministrasian pelayanan perekaman dan pelayanan pengambilan KTP Elektronik.

Adapun proses perekrutan ketiga unsur petugas diatas menurut Kabid Pendataan Dan Informasi Penduduk Kabupaten Mamasa bahwa :

"Di serahkan kepada para Camat untuk menunjuknya, dimana dalam hal ini adalah para staf Kecamatan sendiri dengan kriteria yang sudah ditentukan. Camat kemudian menyurat ke Dinas Kependudukan Dan Pencatatan Sipil Kabupaten Mamasa mengenai nama-nama yang bersangkutan, selanjutnya dibuat Surat Keputusan Bupati. Maka secara personality setiap petugas, DKPS menyerahkan wewenang kepada Camat untuk merekomendasikan" (Wawancara, 4 Maret 2019).

Secara umum, ketiga petugas ini dalam pelaksanaan teknisnya dilapangan bekerja tidak terpisah satu sama lain, dan bekerja secara bergantian sesuai jadwal. Hal ini dilakukan agar pelayanan berjalan terus tanpa istirahat siang, sehingga masyarakat tidak harus menunggu, dengan demikian pelayanan dapat dimaksimalkan. Kenyataan ini peneliti dapatkan melalui observasi dilapangan, dan hasil bincang - bincang dengan operator Kecamatan.

Dari data dan informasi tersebut diatas, menurut penulis perekrutan tersebut masih belum maksimal, karena sebagaimana diketahui bahwa penerapan KTP Elektronik membutuhkan kualifikasi khusus karena merupakan kebijakan yang dilatar belakangi dengan evolusi sistem informasi manajemen, sehingga dibutuhkan seorang sarjana dibidang teknologi informasi agar lebih efektif dan dapat meminimalisir keluhan-keluhan dibidang informatika dengan demikian berimplikasi pada optimalisasi pelayanan.

4) Penyediaan Sarana dan Prasarana 
Pada dasarnya penyediaan sarana dan prasarana untuk penerapan KTP Elektronik terbagi atas dua bagian besar, yaitu perangkat dari pusat dan perangkat dari pemerintah Kabupaten/Kota. Sarana dan prasarana dari pusat terdiri dari perangkat keras dan perangkat lunak yang didistribusikan Direktorat Jenderal Kependudukan Dan Pencatatan Sipil Kementerian Dalam Negeri melalui penyelia dan disampaikan kepada pemerintah Kabupaten Mamasa.

5) Mobilisasi Penduduk Wajib KTP Elektronik

Pada prinsipnya mobilisasi penduduk wajib KTP adalah bagaimana penduduk dapat datang ke tempat pelayanan sesuai dengan jadwal yang tertera dalam surat panggilan, kemudian berjalan lancar, aman, nyaman, tertib dan berhasil melaksanakan penyelesaian proses pelayanan KTP Elektronik. Sehingga dalam hal ini diperlukan kerjasama antara SKPD Kelurahan, Kecamatan dan Disdukcapil.

\section{Implementasi Strategi "Anggaran"}

Sri Mulyani Indrawati, pernah menyatakan bahwa optimalisasi fungsi penganggaran sangat diperlukan demi terwujudnya visi, misi, dan programprogram pemerintah karena baik dalam cakupan geografis maupun dalam jumlah dan ragam populasi bangsa kita demikian kompleks sehingga pasti menghadapi berbagai permasalahan dan kendala yang kompleks pula, sehingga program, kebijakan maupun kegiatan hanya akan tinggal sebagai dokumen siasia dan tidak akan berarti apa-apa jika tidak dikaitkan dengan pembiayaannya. Di sisi lain, keterbatasan anggaran semakin menuntut agar pemanfaatan sumberdaya yang tersedia benar-benar dilakukan secara efektif dan efisien. Kalimat ini tidak mudah untuk disikapi dengan baik jika komitmen semua pihak tidak seiring sejalan.

Sehubungan dengan itu, pemerintah Kabupaten Mamasa menurut Kabid Pendataan Dan Informasi Penduduk bahwa:

"Pemerintah daerah dalam hal ini Bapak Bupati sangat antusias menanyakan kendala yang dihadapi DKPS dalam penerapan KTP Elektronik, dan beliau tidak sungkan menanyakan ketersediaan anggaran yang harus disiapkan untuk mengantisipasi kesuksesan program ini. Namun beliau berpesan bahwa diharapkan seefisien mungkin karena optimalisasi tidak selalu dilihat dari besarnya anggaran, namun bagaimana komitmen semua yang menjalankan program ini untuk bekerjasama dengan baik" (Wawancara, 4 Maret 2019).

Berangkat dari pernyataan tersebut, Dinas Kependudukan Dan Pencatatan Sipil kemudian melakukan pengajuan anggaran melalui RKA Perubahan dengan peningkatan yang signifikan. Dan ketika diajukan anggaran 
ke pemerintah, direspon dengan baik dan bersedia menyiapkan anggaran yang diperlukan mengacu pada juknis dan juklak yang telah diberikan dari pusat, kemudian direspon secara baik pula oleh DPRD Kabupaten Mamasa, dengan harapan program penerapan KTP Elektronik berjalan dengan sukses (Kabid Pendataan Dan Informasi Penduduk Kabupaten Mamasa).

\section{Implementasi Strategi dari segi "Prosedur"}

Prosedur pelaksanaan penerapan KTP Elektronik secara massal yang diterbitkan oleh Kementerian Dalam Negeri oleh Direktorat Jenderal Kependudukan Dan Pencatatan Sipil, sesungguhnya diberikan sebagai acuan kerja bagi Kabupaten/Kota dalam mensukseskan penerapan KTP Elektronik ini. Namun dalam pelaksanaannya memberikan wewenang kepada setiap Kabupaten/Kota untuk membuat strategi dalam menjalankan fungsi-fungsi tersebut sesuai dengan karakteristik dan kondisi geografis setiap daerah.

Berdasarkan hal tersebut, kemudian pemerintah Kabupaten Mamasa membagi fungsi-fungsi tersebut dengan mensinergikan tiga Satuan Kerja Perangkat daerah yaitu : Kelurahan/Desa, Kecamatan dan Kabupaten untuk melaksanakan hal tersebut. Implementasinya secara strategis dipusatkan pelayanan perekamannya di Kecamatan dengan proses/proseduralnya sebagai berikut:

a. Kelurahan/Desa melakukan Penyampaian surat panggilan dengan jadwal dan waktu tertentu. Beberapa Desa/Kelurahan mengumpulkan warganya untuk diangkut ke tempat pelayanan dengan kendaraan yang difasilitasi pemerintah.

b. Kecamatan : Penduduk mendaftar dan menyerahkan surat panggilan kepada petugas, petugas mencocokkan dengan daftar penduduk dan selanjutnya memberi tanda lingkaran pada nama yang sesuai surat panggilan serta memberi nomor antrian.

c. Petugas menyerahkan surat panggilan kepada operator untuk verifikasi biodata penduduk, kemudian memanggil sesuai dengan nomor antrian hingga 10 orang untuk duduk diruang tunggu yang telah disediakan. Jika ada masyarakat yang belum datang, dapat diganti dengan nomor antrian berikutnya.

d. Operator kemudian memulai proses dengan terlebih dahulu memverifikasi nama dan biodata, menanyakan cacat/tidak. Jika normal dan sesuai, operator kemudian mengambil foto Penduduk dengan backround merah jika tahun kelahiran ganjil dan background biru jika tahun kelahiran genap. Jika cacat maka difoto dgn memperlihatkan kecacatannya. (angkat tangan yg cacat).

e. Operator kemudian mempersilahkan penduduk untuk tanda tangan, dan jika yang bersangkutan tidak bisa tanda tangan, operator dapat 
memandu penduduk dengan membubuhkan garis datar dari kiri kekanan pada signature Pad.

f. Selanjutnya perekaman sidik jari dengan urutan : 4 tangan kanan (telunjuk,tengah, manis dan kelingking) secara bersamaan, 4 tangan kiri, kemudian jempol kanan dan jempol kiri bersamaan. Jika cacat tanpa tangan tidak perlu, atau sebahagian saja.

g. Kemudian perekaman iris mata. Operator mengarahkan penduduk agar benar-benar mengkondisikan kornea mata terlihat secara keseluruhan, operator merekam iris mata penduduk dengan jarak kurang lebih $5 \mathrm{~cm}$.

h. Operator melakukan verifikasi kembali dengan cara merekam sidik jari telunjuk kanan dan telunjuk kiri.

i. Operator kemudian meminta pengesahan dengan cara membubuhkan kembali tanda tangan secara elektronik sebagai bukti persetujuan kebenaran data yang bersangkutan.

j. Operator kemudian melakukan pengiriman data dan menyimpannya dalam database Kecamatan, kemudian dikirim ke DKPS.

k. Penerapan e-KTP secara regular, data kemudian diterima oleh DKPS selanjutnya akan diprint out.

\section{KESIMPULAN}

Implementasi Strategi dari segi Program yang dilakukan oleh pemerintah Kabupaten Mamasa dalam penerapan KTP Elektronik (e-KTP) adalah: pembentukan struktur organisasi dalam bentuk kelompok kerja yang terdiri atas pokja Kabupaten dan Pokja Kecamatan, Sosialisasi, Pelaksana Program (Sumber Daya Manusia), penyediaan sarana dan prasarana serta mobilitas penduduk. Sedangkan implementasi strategi dari segi anggaran, pemerintah Kabupaten Mamasa telah berupaya menyiapkan seluruh anggaran yang dibebankan kepada daerah sesuai dengan juknis dari pusat melalui RKA Perubahan dengan jumlah yang signifikan. Implementasi Strategi Prosedur penerapan KTP Elektronik di Kabupaten Mamasa dimulai dari Kelurahan/Desa dalam bentuk mobilisasi dan penyampaian surat undangan, kemudian ke Kecamatan mendaftarkan diri untuk perekaman penduduk, melakukan antrian pemanggilan nama, kemudian verifikasi data, pengambilan foto, tanda tangan, sidik jari, iris mata, kemudian verifikasi sidik jari telunjuk selanjtnya tanda tangan untuk pernyataan atas kebenaran data yang bersangkutan.

\section{SARAN}

Program yang akan dilaksanakan mempertimbangkan sumber daya dan karakteristik daerah, sehingga pada saat perumusan strategi pemakaian sumber daya tidak berlebihan ataupun sebaliknya menghilangkan sumber daya yang 
semestinya ada. Hal ini akan berpengaruh pada saat pengimplementasian strategi, akibatnya orang yang berkompeten ikut melakukan intervensi tidak punya kapasitas. Karena itu jumlah anggota dalam setiap program disesuaikan dengan kebutuhan. Program yang direncanakan hendaknya selalu dikoordinasikan dengan pihak pusat ataupun SKPD terkait agar sinkronisasi dan kebutuhan semua pihak dapat terakomodir. Anggaran KTP Elektronik harus dipastikan dapat terserap maksimal dengan memperjelas barang yang ada dan anggaran yang telah disediakan. Prosedur yang dilakukan sekalipun telah baik, namun sebaiknya ditempat-tempat pelayanan membuat skema prosedur pelayanan KTP Elektronik, sehingga masyarakat semakin memahami dan mengerti tata cara yang akan dilaluinya. Kemudian di tempat-tempat pelayanan sebaiknya ada petugas khusus untuk mengarahkan antrian sehingga masyarakat yang dilayani tidak saling menunggu sehingga efektifitas dan efisiensi waktu dalam pelayanan dapat lebih optimal, dengan demikian dapat menambah jumlah target pelayanan.

\section{DAFTAR PUSTAKA}

Ahmadjayadi, Cahyana. 2011. Sistem Informasi Kepemerintahan Abad 21. Jakarta: Kominfo.

Ali, Zainuddin. 2009. Metode Penelitian Kualitatif. Jakarta: Gramedia Pustaka Utama

Arikunto, Suharsimi. 2010. Prosedur Penelitian Suatu Pendekatan Praktik. Jakarta: Rineka Cipta.

Azhari dan Idham. 2012. Good Governance dan Otonomi Daerah. Yogyakarta: UGM.

Bagong,Suyanto dan Sutinah. 2010. Metode Penelitian Sosial: Berbagai Pendekatan Alternatif. Jakarta: Kencana.

Bungin, Burhan. 2011. Penelitian Kualitatif : Komunikasi, Ekonomi, Kebijakan Publik dan Ilmu Sosial lainnya. Jakarta: Kencana.

Dirgantoro, Crown. 2011. Manajemen Stratejik. Jakarta: Grasindo.

Faisal, Sanapiah. 2010. Format-format Penelitian Sosial. Jakarta: Rineka Cipta.

Hasibuan, M. 2009. Manajemen Dasar, Pengertian dan Masalah. Jakarta: Bumi Aksara.

Hunger dan Wheelen. 2010. Manajemen Strategis. Yogyakarta: Andi.

Lukiastuti, Fitri, Kurniawan dan Muliawan. 2013. Manajemen Strategik dalam Organisasi. Yogyakarta: MedPress. 
Marzuki. 2011. Metode Penelitian Sosial. Bogor: Ghalia Indonesia.

Moleong, Lexy J. 2010. Metode Penelitian Kualitatif. Bandung: Remaja Rosdakarya.

Mulyo, Slamet. 2013. RC4 sebagai Security pada Database Aplikasi SIAK. Yogyakarta: Gadjah Mada University Press.

Nasir. 2009. Metode Penelitian. Bogor: Ghalia Indonesia.

Nawawi. 2011. Manajemen Startegik Organisasi Non Frofit Bidang Pemerintahan. Yogyakarta: Gadjah Mada University Press.

Nugroho, Riant. 2010. Kebijakan Publik: Formulasi, Implementasi, dan Evaluasi. Jakarta: Alexmedia Competindo.

Pusat Pendidikan dan Pelatihan Pengawasan Badan Pengawasan Keuangan dan Pembangunan (BPKP). 2007. Akuntabilitas Instansi Pemerintah. Edisi kelima. Jakarta: BPKP.

Purwanto. 2010. Instrumen Penelitian Sosial dan Pendidikan.Yogyakarta: Pustaka Pelajar.

Purwanto, Iwan. 2012. Manajemen Strategi. Bandung: Irama Widya.

Rangkuti. 2011. Analisis SWOT Tehnik Membedah Kasus Bisnis: Reorientasi Konsep Perencanaan Strategi. Yogyakarta: Pustaka Pelajar.

Riyadi dan Bratakusumah, Deddy Supriyadi. 2011. Perencanaan Pembangunan Daerah. Jakarta: Gramedia Pustaka Utama.

Salusu. 2010. Pengambilan Keputusan Stratejik untuk Organisasi Publik dan Organisasi Non Profit. Jakarta: Grasindo.

Setiawan, H.P. dan Zulkieflimansyah. 2012. Manajemen Strategi (Buku Seri Manajemen). Jakarta: Lembaga Penerbit Fakultas Ekonomi Universitas Indonesia.

Siagian, Sondang P. 2009. Manajemen Stratejik. Jakarta: Bumi Aksara.

Siregar, Syofian P. 2010. Statistik Deskriptif Untuk Penelitian. Jakarta: Raja Grafindo Persada.

Sistaningrum. 2010. Pengaruh Implementasi Kebijakan Pertanian Terhadap Struktur Penguasaan Tanah dan Dampaknya Terhadap Kesejahteraan Petani. Yogyakarta: Graha Ilmu.

Soetomo. 2010. Strategi-strategi Pembangunan Masyarakat. Yogyakarta: Pustaka Pelajar. 
Suaedi, Falih. 2013. E-Government sebagai Sarana Revitalisasi Birokrasi. Yogyakarta: Graha Ilmu.

Sugiyono. 2011. Metode Penelitian Pendidikan: Pendekatan Kualitatif, Kuantitatif, dan R\&D. Bandung: Alfabeta.

Sukanto, R. 2009. Manajemen Strategi. Yogyakarta: BPFE.

Tjiptoherijanto. 2010. Kelembagaan Kependudukan Era Otonomi Daerah. Jakarta: Rajawali Press.

Tunggal, Amin Widjaya. 2010. Manajemen Strategik. Jakarta: Harvarindo.

Vurtiana, Melita. 2012. Metodologi Penelitian. Bandung : Alfabeta.

Wahab, Solichin A. 2009. Analisis Kebijakan dari Formulasi ke Implementasi Kebijakan. Jakarta: Bumi Aksara.

Wesasa, Silih Agung. 2012. Strategi Publik Relations. Jakarta: Gramedia Pustaka Utama.

Wahyudi. 2010. Manajemen Strategik. Bandung: Alfabeta.

Wibawa, Samodra. 2009. Kebijakan Publik. Jakarta: Intermedia.

Widodo. 2009. Manajemen Strategis Sektor Publik. Jakarta: Gramedia Pustaka Utama.

Winarno, Budi. 2010. Kebijakan Publik: Teori dan Proses. Yogyakarta: Media Pressindo.

Wrihatnolo dan Nugroho. 2012. Manajemen Pembangunan Indonesia, Sebuah Pengantar dan Panduan. Jakarta: Elex Media Komputindo. 